\title{
Exhumation of a Hero, Colonel Ben Milam, Milam Park Renovation, Phase I
}

Cynthia L. Tennis

Center for Archaeological Research

Follow this and additional works at: https://scholarworks.sfasu.edu/ita

Part of the American Material Culture Commons, Archaeological Anthropology Commons, Environmental Studies Commons, Other American Studies Commons, Other Arts and Humanities Commons, Other History of Art, Architecture, and Archaeology Commons, and the United States History Commons

Tell us how this article helped you.

This Article is brought to you for free and open access by the Center for Regional Heritage Research at SFA ScholarWorks. It has been accepted for inclusion in Index of Texas Archaeology: Open Access Gray Literature from the Lone Star State by an authorized editor of SFA ScholarWorks. For more information, please contact cdsscholarworks@sfasu.edu. 


\section{Exhumation of a Hero, Colonel Ben Milam, Milam Park Renovation, Phase I \\ Creative Commons License \\ (c) (1) \& 8}

This work is licensed under a Creative Commons Attribution-NonCommercial 4.0 International License 


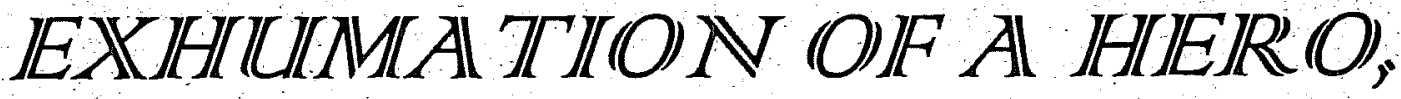 COOILONNELL IBIEN MIILAMMI

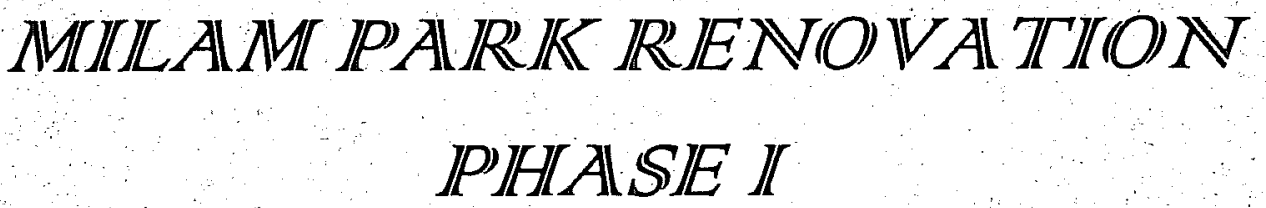

\section{Cynthia L. Tennis}

with contributions by

Douglas W. Owsley, Karin L. Sandness, and Barbara A. Winkler

Center for Archaeological Research The University of Texas at San Antonio Archaeological Survey Report, No. 223 



\section{FRONTISPIECE}

Colonel Benjamin Rush Milam.

Artist unknown.

Courtesy of Mrs. John Privett, a great-niece of Ben Milam. 



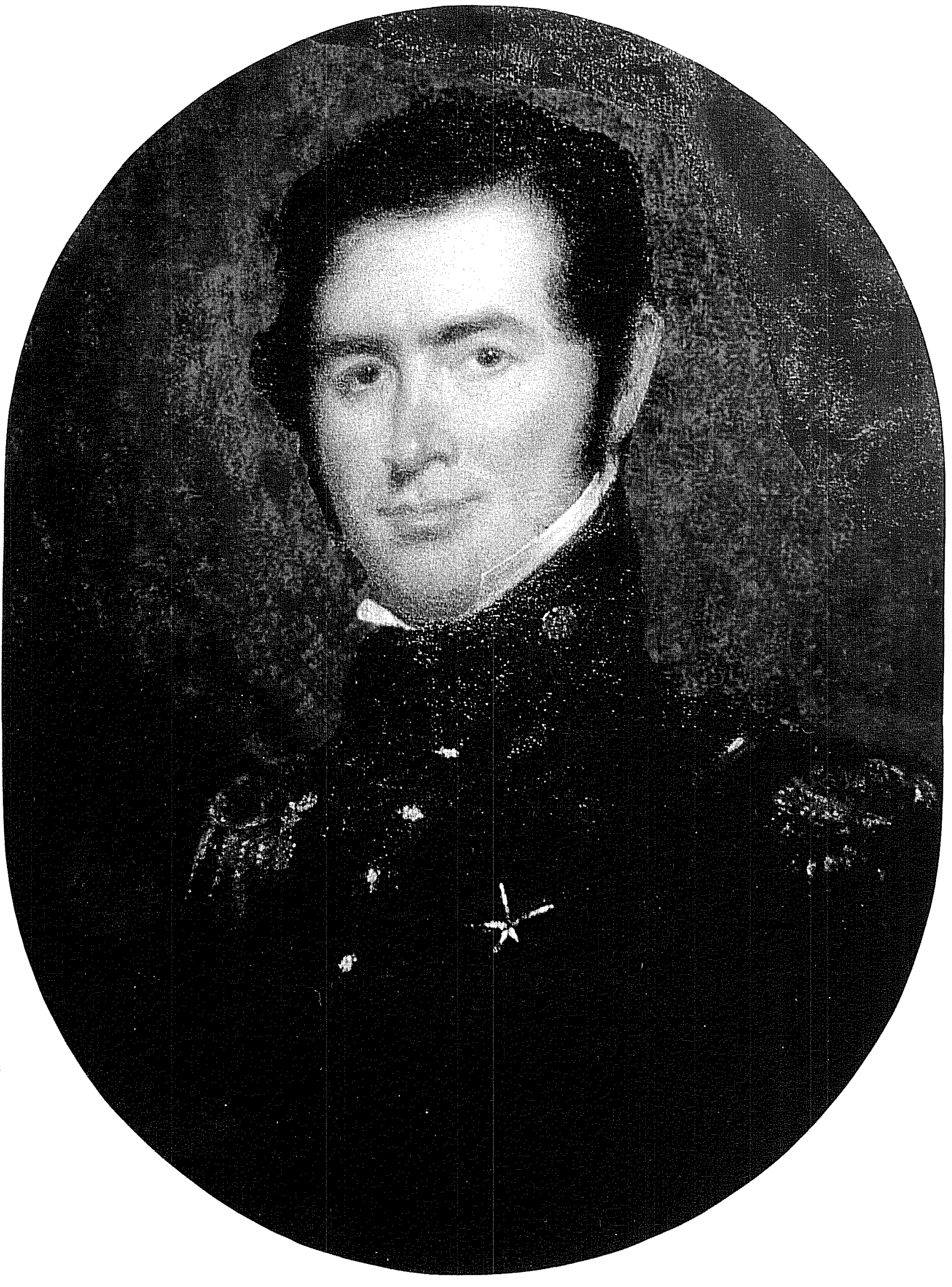





\title{
EXHUMATION OF A HERO, COLONEL BEN MILAM MILAM PARK RENOVATION PHASE I
}

\author{
Cynthia L. Tennis \\ with contributions by \\ Douglas W. Owsley, Karin L. Sandness, \\ and Barbara A. Winkler
}

\author{
Jack D. Eaton and Robert J. Hard \\ Principal Investigators
}

Texas Antiquities Permit No. 1177

@copyright

Center for Archaeological Research The University of Texas at San Antonio Archaeological Survey Report, No. 223 
The following information is provided in accordance with the General Rules of Practice and Procedure, Chapter 41.11 (Investigative Reports), Texas Antiquities Committee:

1. Type of investigation: Excavation

2. Project name: Milam Park Renovation Phase I

3. County: Bexar

4. Principal Investigator: Jack D. Eaton; co-principal investigator: Robert J. Hard

5. Name and location of sponsoring agency: San Antonio Department of Parks and Recreation, San Antonio, Texas

6. Texas Antiquities Permit No. 1177

7. Published by the Center for Archaeological Research of The University of Texas at San Antonio, San Antonio, Texas 78249-0658, 1995

A list of publications by the Center for Archaeological Research is available. Call (210) 691-4378 or write to the Center for Archaeological Research, The University of Texas at San Antonio, 6900 North Loop 1604 West, San Antonio, Texas 78249-0658. 


\begin{abstract}
During the last part of 1992 and the beginning of 1993, archaeologists from the Center for Archaeological Research of The University of Texas at San Antonio monitored the initial stages of Phase I renovation and construction at Milam Park, New City Block 330. The work for this stage consisted of the removal of portions of an existing wall, ground preparation and leveling in the center of the park, construction of the footing for the new kiosk, and grading for a construction access ramp from Houston Street. Additionally, the excavation

in an attempt to establish the exact location of the grave of the Texas hero for whom the park is named, Col. Benjamin Milam. All work was stopped when evidence of a human burial was discovered.

The exhumation, inspection, and temporary curation of the burial believed to be that of Benjamin Milam was subsequently completed under a revision of the existing Texas Antiquities Permit No. 1177.
\end{abstract} of three 4- $\mathrm{x}-20$ - $\mathrm{ft}$ backhoe trenches was monitored 
ABSTRACT $\ldots \ldots \ldots \ldots \ldots \ldots \ldots \ldots \ldots \ldots \ldots \ldots \ldots \ldots \ldots \ldots \ldots \ldots \ldots$

LIST OF FIGURES $\ldots \ldots \ldots \ldots \ldots \ldots \ldots \ldots \ldots \ldots \ldots \ldots \ldots \ldots \ldots \ldots \ldots \ldots \ldots \ldots \ldots$

ACKNOWLEDGMENTS $\ldots \ldots \ldots \ldots \ldots \ldots \ldots \ldots \ldots \ldots \ldots \ldots \ldots \ldots \ldots \ldots \ldots$ iii

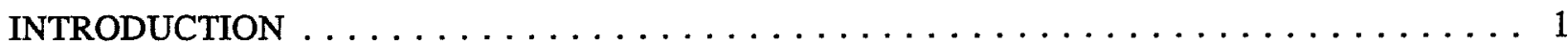

HISTORICAL BACKGROUND $\ldots \ldots \ldots \ldots \ldots \ldots \ldots \ldots \ldots \ldots \ldots \ldots \ldots \ldots \ldots \ldots \ldots \ldots$

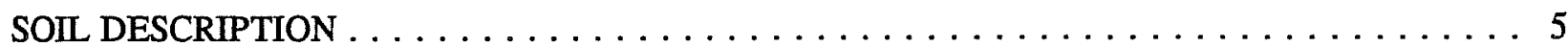

MONITORING PHASE $\ldots \ldots \ldots \ldots \ldots \ldots \ldots \ldots \ldots \ldots \ldots \ldots \ldots \ldots \ldots \ldots \ldots \ldots$

EXCAVATION PHASE $\ldots \ldots \ldots \ldots \ldots \ldots \ldots \ldots \ldots \ldots \ldots \ldots \ldots \ldots \ldots \ldots$

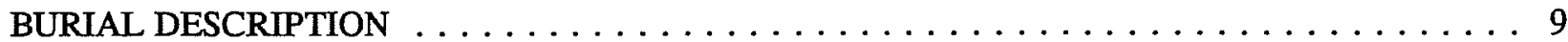

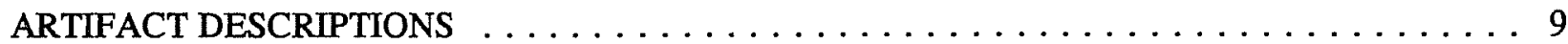

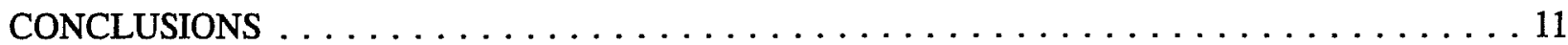

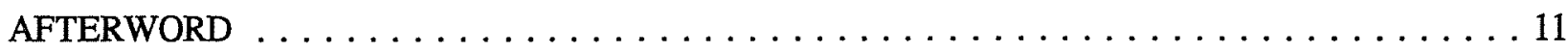

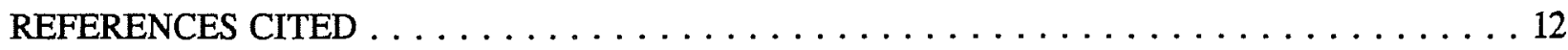

APPENDIX A: ANALYSIS OF THE BEN MILAM SKELETON

Barbara A. Winkler . . . . . . . . . . . . . . . . . . . . . 13

APPENDIX B: ANALYSIS OF THE SKELETAL REMAINS

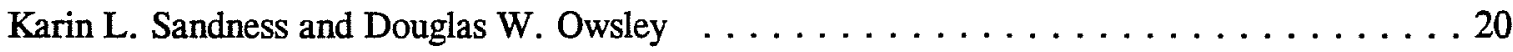

\section{FIGURES}

1. Location maps. . . . . . . . . . . . . . . 2

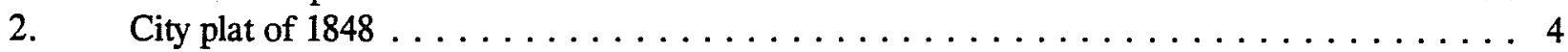

3. Location of trenches and burial within Milam Park ................ 7

4. Plan view of Ben Milam burial within a wooden casket $\ldots \ldots \ldots \ldots \ldots \ldots \ldots \ldots$ 


\section{ACKNOWLEDGMENTS}

I would like to acknowledge the many people and organizations that supported this project from the onset. The professionalism displayed by Dale Bransford and Julie Lipton of the San Antonio Department of Parks and Recreation greatly expedited this endeavor. The enthusiastic and positive attitude of the Milam family as well as the members of the Daughters of the Republic of Texas, the Sons of the Republic of Texas, the San Antonio Conservation Society, and the Friends of Milam Park is appreciated. The research compiled and shared by Bob Benavides, Hovey Cowles, Kevin Young, Ken Brown, and Waynne Cox was extremely helpful. The assistance of the entire contractor's crew from Van Delden Company facilitated the project's completion.

Additional thanks are due the following CAR staff for their field assistance and support: Jack Eaton, Anne Fox, José Zapata, Barbara Meissner, Mary Vaughan, and Robert Rector. I would also like to acknowledge Marcie Renner, CAR editor, and Robert J. Hard, CAR director, for their assistance with this report.
I would like to acknowledge the many individuals from the medical and physical anthropology fields who participated in the examination of the remains of Col. Milam. Among these are Bexar County coroner Vincent DiMaio, M.D., who initially verified the presence of the exit wound in the skull; Albert Sanders, M.D., David Henkes, M.D., and Carlos Orozco, M.D. who assisted Barbara A. Winkler, Ph.D., of UTSA during the physical anthropological study. My appreciation is also extended to Karin Sandness and Doug Owsley, $\mathrm{Ph} . D$., at the National Museum of Natural History, Smithsonian Institution, for their involvement in this project. 



\section{INTRODUCTION}

In November 1992, the Center for Archaeological Research (CAR) of The University of Texas at San Antonio (UTSA) entered into a contract with the San Antonio Department of Parks and Recreation (DPR) to conduct archival research and monitor construction excavations for Phase I of the Milam Park renovation project. Milam Park is located in downtown San Antonio, bordered by Houston and Commerce streets on the north and south, and Santa Rosa and N. San Saba streets on the east and west (Figure 1). The focus of this phase of the program was the center of the park where a $30-\mathrm{x}-40-\mathrm{ft}$ segment of ground was to be excavated to a depth of approximately 18 inches below the present surface to provide a level base for the construction of a kiosk (Figure 1) given to San Antonio by its sister city, Guadalajara, Mexico.

Before work began, several members of the Bexar County Historical Commission (BCHC) voiced concerns over the planned location of the kiosk. While it had long been accepted that Milam Park was the site of the final resting place for the Texas hero, Ben Milam, the exact location of his grave had been lost over the years. Archival records indicated that the most likely place for the grave would be the center or just north of the center of the park. An agreement was reached between the BCHC, the Friends of Milam Park, and the DPR to attempt to locate the grave by digging a fourfoot-wide backhoe trench from the center of the park, $20 \mathrm{ft}$ north to the edge of the existing sidewalk.

A concrete slab measuring $57 \times 57$ x 18 inches was uncovered 48 inches west of the park center mark previously established by the city surveyors. This slab was probably the base of the Milam monument which had been moved in prior years. Therefore, the initial backhoe trench began at the north edge of the slab instead of at the actual surveyed center of the park.

No evidence of a burial was found during this initial trenching operation. Subsequent meetings between representatives of the $\mathrm{BCHC}$, the Daughters of the Republic of Texas (DRT), the
Sons of the Republic of Texas, the San Antonio Conservation Society, and the DPR resulted in an agreement to continue backhoe trench investigations in the immediate vicinity of the cement monument base. An additional backhoe trench was dug to a depth of four feet, extending the original trench $10 \mathrm{ft}$ to the south. Another trench was dug perpendicular to the north/south trench, intersecting it at the center mark. At a depth of $3.5 \mathrm{ft}$ a burial was encountered. On January 22, 1993, hand excavation of the burial began. Two staff members from CAR, Cynthia Tennis and José Zapata, uncovered the remains. After photographs and drawings were made, the remains were removed and transported to the CAR laboratory. Staff volunteers screened over 70 percent of the backhoe dirt and all the burial matrix soil was bagged and returned to the lab for processing.

\section{HISTORICAL BACKGROUND}

"Old Ben Milam," for whom Milam Park is named, is renowned for his role in the fight for Texas independence from Mexico. Benjamin Rush Milam was born October 20,1788, the fifth of six children. His birthplace was probably Frankfort, Kentucky, and he spent his early years in Kentucky. At age 22 he served with the Eighth Regiment of the Kentucky Militia (Day 1964).

In 1818 Milam came to Texas, then a part of Spain, to trade with the Comanche Indians along the Colorado River. He evidently decided to stay, and by 1820 he had enlisted in the Mexican Army. Milam served as a colonel during the Mexican revolution against Spain until 1822. In 1824 he became a Mexican citizen in order to obtain permission to establish a colony of 300 families in an area that today includes all of Hays and Blanco counties as well as parts of Comal, Caldwell, Bastrop, and Travis counties. This effort, begun in 1826 , was unsuccessful, as the 300 -family quota was not reached in the first six years of the contract. Between 1826 and 1829, Milam was involved in various other unsuccessful land deals as well as numerous gold and silver speculations. Milam spent the early half of the 1830 s on his 

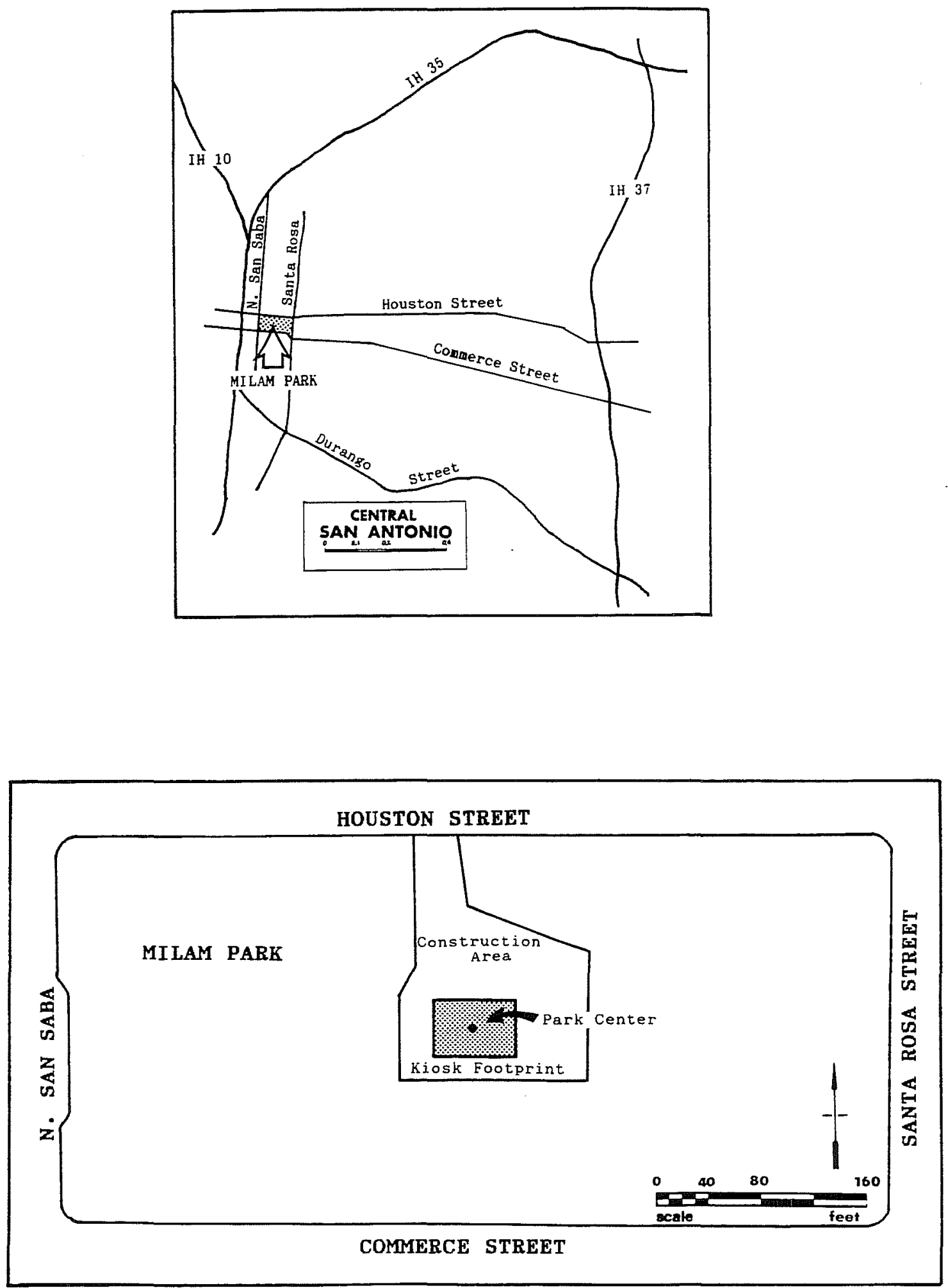

Figure 1. Location maps. Location of Milam Park in downtown San Antonio (upper) and of the planned kiosk within the park (lower). 
homestead on the Red River but by 1834 he was again involved in political events in Texas. During this period unrest was brewing over Santa Anna's attempted overthrow of the 1824 Mexican constitution. While returning from a mission to obtain clear land titles for his neighbors, Milam was arrested by troops under the command of General Cos, Santa Anna's representative in San Antonio. He spent several months in various Mexican prisons, finally ending up in Monterrey. Milam escaped from prison and joined a group of Texans under Captain Collinsworth in Goliad, where continuing unrest had escalated to the point of open revolt. After the successful attack on Goliad, Milam went to Gonzales where he volunteered for the newly formed Texas Army under Stephen F. Austin (Day 1964:115-121).

As the Texas Army advanced to within a half-mile of San Antonio, their next target, a convention was under way in San Felipe to decide whether the Texans were fighting to gain independence from Mexico or to support the 1824 Mexican Constitution by opposing Santa Anna. When the delegates chose to support the constitution, the officers of the contingent outside San Antonio decided to withdraw to Gonzales or Goliad and await the end of the winter in relative safety. Ben Milam, however, viewed retreat as offensive. He is credited with drawing a line in the dust and declaring "Who will go with old Ben Milam into San Antonio? Who will follow old Ben Milam?” (Nevin 1975:75).

The 300 men who rallied to Milam's call were divided into two units, one led by Francis Johnson, the other by Milam himself. On December 5, 1835, they began their assault on General Cós's troops in San Antonio. The Texans fought their way to just north of Military Plaza and set up headquarters in two houses, the de la Garza house and the Veramendi house (Nevin 1975:75). On December 7,1835 , Milam was fatally wounded by a single bullet to the head, reportedly fired from a British Baker Rifle (Kevin Young, personal communication 1993) by Felix de la Garza, a sharpshooter in the Mexican chasseur company (Taylor 1935:65). Milam was buried where he fell in the east yard of the Veramendi house. The
Texans went on to force General Cós's surrender of the city and the Alamo. It was this conflict, the Battle of San Antonio de Bejar, inspired and led by Col. Benjamin Milam, which led to the famous Battle of the Alamo and eventually to Texas's independence from Mexico.

The official history of the block of land now known as Milam Park began April 3, 1848. On this date the city council, acting on a petition from the Catholic parish priest, adopted a resolution setting aside an eight-acre area adjoining and including the "old Campo Santo" for cemetery use (City Council Minutes [CCM], Office of the City Clerk. City Hall, San Antonio, Texas, 1848:A:135-137). An 1848 city plat (Figure 2) shows an east/west dividing line, separating the area into a Catholic cemetery and a city cemetery (Bexar County Archives [BCA], Bexar County Courthouse, San Antonio, Texas, 1848:City Survey Book 1). City council minutes note the portion designated as city cemetery was already in use as a "public burial ground" at that time (CCM, 1848:A:135-137).

City council minutes (CCM, 1848:A:135-137) record the acceptance of these plats with a dividing line running east/west through the center of the cemetery, and city streets bordering the four sides. By 1904 these streets had become known as Commerce Street on the south, North San Saba on the east, Zavala on the north (now covered by Santa Rosa Hospital), and North Santa Rosa on the west (Sanborn Insurance Map 1904, United States Library of Congress Microfilm Collection, John Peace Library, The University of Texas at San Antonio). The dividing line was widened into a street known today as Houston Street.

Several years after his death, Ben Milam's body was exhumed from the Veramendi yard. Two accounts of this event cite the leader of this endeavor as either Col. John H. Moore on December 7, 1846 (Eddie James to DeShield, interview, DeShield Papers, Daughters of the Republic of Texas Library [DRTL], San Antonio, Texas) or members of the Alamo Masonic Lodge No. 44 in 1848 (DRTL, Records and Proceedlings of Alamo Lodge No. 44, minutes, 7 December 


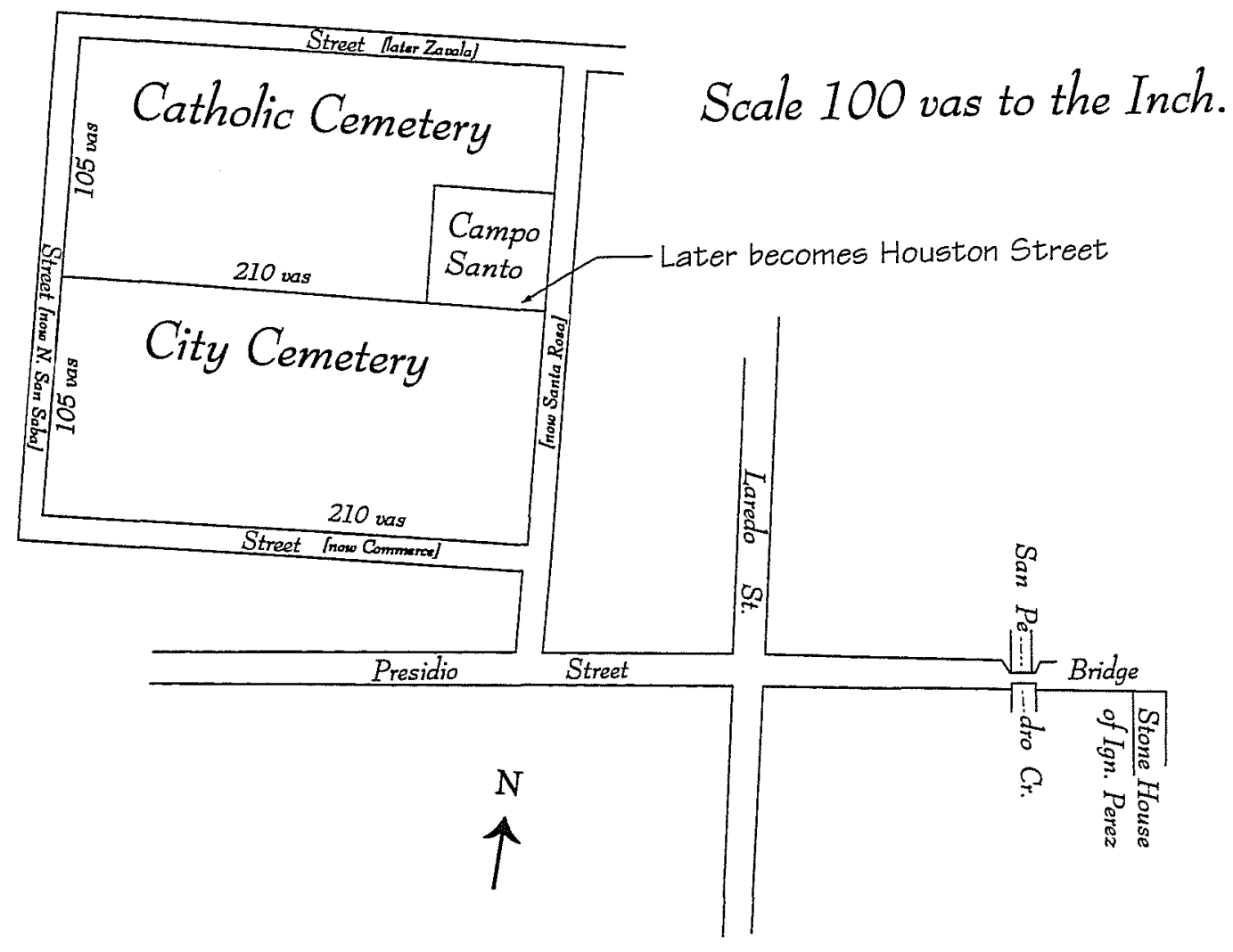

Figure 2. City plat of 1848. Adapted from the original 1848 Plat and Field Notes (BCA 1848:City Survey Book 1). Vas= varas, approximately $2.8 \mathrm{ft}$.

1848). "Though buried some ten years, the body, it is said, was unchanged, and the old warrior looked natural. The boots in which he was buried were sound and would have done to wear again. The black silk kerchief in which his head was tied looked perfectly new, except for the bloodspots" (DeShield, DRTL). Both accounts agree however, that the remains of Ben Milam were reburied with appropriate honors in the city cemetery. No mention is made in either account of a grave marker being placed at this time. Little attention seems to have been paid to the grave site of Ben Milam for several years.

This area was evidently used as a public cemetery for only a short period because two years after it officially became the city cemetery, city council was again addressing the need for public cemetery lands. In October 1850 the council appointed a committee to assess the feasibility of locating a public cemetery on city property near the powder house east of the then city limits (CCM, 1850: $\mathrm{B}: 111$ ). Although a report was requested by the next meeting, action was actually not begun again until January 1853. At this time a resolution was passed for the survey of 20 acres of land on the hill northwest of the powder house to be called a city cemetery (CCM, 1853B:203-204). By June 1853, seven city ordinances were approved for the management of this new cemetery (CCM, 1853: B:219-220).

In July 1878, a San Antonio Express supplement reported that "some days ago" the mayor, The Honorable V. O. King, had located the resting place of Ben Milam (San Antonio Express [SAE], 18 July 1878). On July 17, 1878, a party of gentlemen gathered at that grave to mark it with a 
plain, flat stone bearing Milam's name. This stone remained the only marker of Milam's grave for more than 20 years (SAE, 7 December 1899; 4 April 1900). During this time public attention was directed elsewhere and the old cemetery became a "choice roping ground for the poundman in quest of stray stock," and the flat limestone marker a popular place for the city drunk "to sleep off his heavy drunken stupor" (SAE, 7 December 1899).

In 1884 the city council decided to turn the old cemetery, unused since 1853 , into a city park. In a special meeting on January 8,1884 , a resolution was adopted to change the name of the then Milam Square, located northeast of the Alamo between Avenue C (Broadway) and Avenue D (Alamo Street) just south of Jones Avenue (City Directory [CD] 1883), to Maverick Square. The old cemetery was renamed Milam Square or Park in honor of the hero buried there (CCM, 1884: B:569).

In September 1899, city aldermen voted unanimously to appropriate $\$ 250$ for the erection of a marble monument to mark the grave of Ben Milam (SAE, 19 September 1899). In December of that year the DeZavala Chapter of the DRT petitioned the city council, requesting that the funds appropriated by the city for the Milam monument be combined with $\$ 500$ collected by the chapter for the same purpose (DRTL, DRT Annual Meeting Minutes [AMM], April 20 1900).

Frank Teich, a local sculptor and quarry owner, was commissioned to design and construct the monument. A model of his original design, a 17-fttall marble base topped by a life-size statue of Ben Milam, was displayed in City Hall December 6, 1899 (SAE, 7 December 1899). Erection of a pedestal, somewhat smaller than the one originally designed by Teich, in the center of Milam Park began April 3, 1900 (SAE, 4 April 1900). The planned statue of Milam was never added.

Minutes from a DRT meeting recount Mr. Teich's assurance that the monument he erected had been placed directly over the grave of Ben Milam, in the same spot where the stone slab had lain (DRTL, DRT AMM, April 20, 1910). From as early as 1903 until at least 1950, periodic ceremonies were held at Milam's grave to commemorate fallen Texas heroes (SAE, 7 March 1903, 7 March 1946; San Antonio Light [SAL], 7 March 1933). These ceremonies were eventually discontinued and the significance of Milam Park faded from community consciousness.

Although the DRT monument was never topped by the originally planned statue of Milam, the Texas Centennial Commission did erect a monument at the west end of Milam Park in 1938. This monument, dedicated to Texas heroes, was topped with a life-size statue of Ben Milam ( $S A E, 8$ September 1938). Teich's marble pedestal remained as a marker over Milam's grave until 1976, when it was relocated to the west end of the park during a park beautification project. Evidently the significance of this small monument and its location was overlooked by park planners who probably did not realize it was actually the headstone of a hero's grave. New walkways were laid and fresh landscaping done, effectively erasing any reference to the exact location of this important spot; these actions necessitated the current relocation and exhumation operation.

\section{SOIL DESCRIPTION}

Houston Black Clay is the dominant soil type in the downtown San Antonio area. This soil is dark grey to black. Its main characteristic is its potential for shrinking and swelling with changes in moisture and temperature. There is typically a zone three to six feet below the surface where the soil matrix is constantly mixed and turned. This action can cause displacement or disruption in subsurface deposits such as archaeological features (Collins 1992). The substratum associated with Houston Black Clay in the downtown San Antonio area is a light brownish-grey in color (Taylor et al. 1966:4). 


\section{MONITORING PHASE}

On December 15, 1992, park renovations began with the construction of a heavy equipment access ramp off Houston Street. Portions of the city sidewalk and curbing were removed, along with a section of the 18-inch stone wall which bordered the park. A Bobcat machine was used to remove some of the topsoil near the street to create a gentle slope from street level to the center of the park. The soil, probably added recently for landscaping, was a dark brown loam throughout; the depth of removal never exceeded 18 inches. The only disturbances seen during this operation were recent ones created by the installation of water and sprinkler system lines.

Bobcat work switched to ground preparation and leveling in the center of the park where the kiosk would be located. A benchmark was established at $652.43 \mathrm{ft}$ above mean sea level by a city survey crew . A 30-x-40-ft area in the exact center of the park, also established by city surveyors, was then excavated by the Bobcat to the benchmark level. This area would become the footpad for the construction of the kiosk. Due to the upward slope of the ground, the depth of the leveling varied from three inches in the southeast corner to 18 inches in the northwest corner.

Beneath the grass and topsoil was a layer of very red landscape sand. This sand layer was visible in all four profiles of the footpad. It began six inches below the present ground surface and varied in thickness from four to six inches. Three capped water pipes extended into the area from the north on a level even with the bottom of the sand layer. A crushed Schlitz Beer can with a bar code label was also recovered at the bottom of the sandy layer. The presence of the bar code on the can, a pricing practice begun in the 1970s (Maxwell 1993:96), firmly associates this red sand layer with the landscape work done during the 1976 park renovation.

A concrete slab was encountered four feet west of the park center mark. The top of the slab was six inches below the present surface, about midway into the red sandy layer. When fully uncovered it measured $57 \times 57 \times 18$ inches and was made of a very crude, early concrete. The mix consisted of large gravel, pieces of yellow brick, and several large chunks of granite. The presence of the yellow brick and the granite, in particular, strongly suggests this concrete was made from scrap material from Mr. Teich's quarry yard. Additionally, the monument pedestal made by Teich and moved in 1976 has a 60-square-inch base. These data, combined with the slab's location of only four feet away from the modern center of the park, reveal that this slab was, in all probability, the foundation for the 1900 marble grave marker of Ben Milam.

Upon comparing the 1904 Sanborn map of Milam Park with the measurements made by the city surveyors, it was noted that the park is $25.6 \mathrm{ft}$ narrower now than at the earlier date, probably due to widening of city streets. It was, however, impossible to tell if the area had been taken from the Commerce Street side, the Houston Street side, or some from each; therefore, the exact center of the park at the time of Milam's burial was still unclear. Because of the uncertainty of the park center, the concrete foundation slab was used as the starting point for the backhoe trenches.

The backhoe trenches were used to identify soil changes that would indicate the location of any grave pit in the area around the concrete slab (Figure 3). Two CAR staff members monitored the backhoe excavations which dug the trenches in sixinch increments. The initial trench was three feet wide and extended $20 \mathrm{ft}$ north from the northern edge of the slab. This trench, N1, was excavated to three feet below the historic surface (the top of the black soil layer immediately below the red sand layer). This depth was judged sufficient to detect any grave pit in the area. No disturbances or soil changes were visible in this trench. The soil was consistently Houston Black Clay.

Work was suspended for the Christmas and New Year's holidays. Due to the length of time the site would be vacant, Trench N1 was backfilled with easily identifiable construction caliche. 


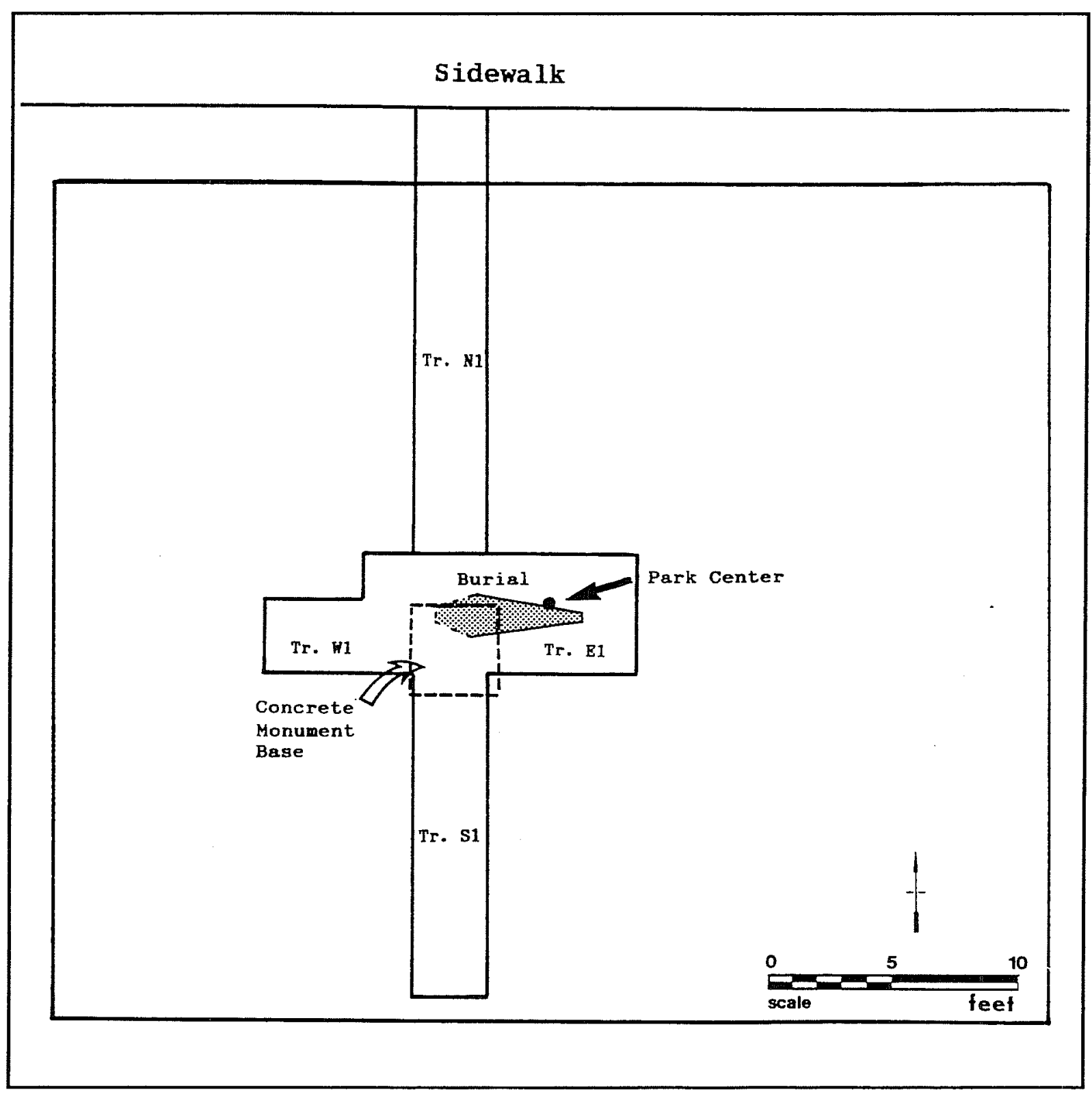

Figure 3. Location of trenches and burial within Milam Park.

Because of rainy weather, work did not resume until January 11, 1993. The wet condition of the ground and the small confines of the construction footpad made it necessary for the backhoe to remain outside the footpad borders. The concrete slab was removed and the second backhoe trench, $\mathrm{S} 1$, was dug beginning where the fill marked the southern limit of trench N1. Trench S1 ran south, directly underneath the original location of the slab, to a total length of $15 \mathrm{ft}$. Again, no soil change from the homogeneous Houston Black Clay was noted within the first three feet. At the threefoot depth in the far south portion of the trench, a slight lightening of the soil was noted. The southernmost five feet of trench S1 were excavated to a depth of five feet to investigate this change which proved to be the light brownish-grey clay substratum associated with Houston Black soils in the area (Taylor et al. 1966:4). No other changes or disturbances were present. 
A third trench was dug perpendicular to trench S1 beginning where the still-open trench $S 1$ connected with the previously filled trench $\mathrm{N} 1$. This trench, W1, extended westward six feet and was excavated to a depth of four feet below the leveled surface. Again, no soil change was visible within the first $3.5 \mathrm{ft}$. From $3.5-4 \mathrm{ft}$, an increase in moisture and slight lightening in soil color was noticed, very similar to the change noted in trench S1. No other changes or disturbances were visible.

The fourth trench, E1, was actually a six-foot long eastward extension of trench W1. Again, no soil change that would indicate a grave pit was present. However, at a depth of $3.5 \mathrm{ft}$ below the leveled surface, an object was seen protruding from the bottom of the trench. Closer inspection revealed the top portion of a vertebrae. Hand clearing revealed what appeared to be part of a collapsed rib cage, confirming the presence of a human burial. After the exposed portion of the burial was covered with a sheet of plywood for protection, the trench was carefully widened to the north and the east end was extended an additional two feet to provide room for hand excavations.

\section{EXCAVATION PHASE}

Ten days elapsed while the scope of work was expanded to include the actual exhumation. During this time, the burial site was secured by DPR rangers. Heavy rains several days before the excavation was scheduled to begin caused additional problems. The first field day was spent pumping water out of trench S1 which, fortunately, was deeper than the burial trench and had acted as a catch basin for the rain run-off. Although very little water had actually collected in the burial trench, the floor of the trench was extremely wet and sticky. Paving stones were laid around the perimeter of the trench floor to give CAR staff members a dry place from which to work. Water was observed seeping through the north wall near the head area of the burial and frequent bailing was necessary to control the water level. A small diversion trench was finally dug to direct water away from the burial area.
The overburden was carefully removed by shovel to within two inches above the position of the visible vertebrae and rib cage. Dirt, mud actually, from this procedure was screened through $1 / 4$-inch mesh screen. At this point, no indications of a coffin lid or outline were evident, and still no soil change to identify the grave pit itself was visible.

Excavation began below and outside the estimated foot of the coffin and worked upward and inward. As the coffin outline began to appear, it was followed toward the head area. The coffin flared outward as it neared the chest area and appeared to be of the "toe pincher" or hexagonal variety. However, from the point where the coffin walls should have begun to narrow again from the shoulders to the head, no traces of wood remained. Except for two coffin nails on each side and one large nail across the top, the entire upper third of the coffin had deteriorated. At this point the significance of the seep in the north wall became apparent-evidently, water had been moving across the upper third of the coffin for some time, unfortunately speeding the deterioration of the skeletal remains as well as those of the coffin.

Excavation of the coffin matrix began again in the lower leg area since the coffin outline was visible there. Soil was removed with trowels until bone was encountered. Then soil was removed from around the bone with bamboo splints. Excavation continued in this manner until all skeletal remains, with the exception of the foot area, were uncovered in situ. The foot bone area was removed in a block and returned to the lab for complete recovery of all small bones. The long bones and bones from the lower half of the torso were in extremely good condition. Unfortunately, due to accidental damage during the backhoe excavation stage and damage caused by the long-term water seepage, very little of the upper chest and shoulder area remained and none of the skull was present.

Three whole and one half bone buttons from the pelvis area and one shell button from the neck area were recovered in situ. Photographs and sketches were made. Bones were labeled right or left, wrapped in tissue paper and transported to the CAR lab for processing and further study. All soil 
from within the coffin area was bagged and returned to the lab for water screening.

During the backhoe operation, back dirt from each trench had been placed in separate piles. The back dirt from the two trenches most closely associated with the actual burial site, E1 and W1, was screened through $1 / 4$-inch mesh. Numerous skull fragments and sections of the lower mandible and maxilla were recovered in this manner.

\section{BURIAL DESCRIPTIONS}

\section{PHYSICAL PLACEMENT}

The body was resting in an extended, supine position oriented east-west, with the head to the west. The arms were in a flexed position with the hands crossed over the abdomen, right hand over the left (Figure 4).

\section{COFFIN DESCRIPTION}

The coffin, probably pine, was the hexagonal type common in rural Texas until the 1890s (Fox 1984). Exact measurement of the coffin length was not possible due to water damage of the upper section, but an estimate based on nail placement indicates an overall length of $5.5 \mathrm{ft}$ and a width varying from six inches at the toe to $1.5 \mathrm{ft}$ at the elbow. The remaining wood was in extremely poor condition and the coffin had been compressed to a maximum thickness of only four inches.

\section{ARTIFACT DESCRIPTIONS}

\section{BUTTONS}

\section{Bone}

Five complete and one half bone buttons were recovered from the burial. Three of the complete buttons and the one half button were found in situ during excavation (Figure 4); the remaining two were discovered in the lab while the bones were being washed. One of these was found in the clay associated with the left tibia, the other was within the dirt block containing the foot bones. Each button is ${ }^{11} / 16$ inch in diameter and has five holes in a recessed mid-section.

Shell

Two white shell buttons were recovered from the burial. The button found in situ in the neck area measures $1 / 4$ inch in diameter and has three holes. The other shell button was found during washing in association with the middle vertebrae. This button measures $3 / 8$ inch in diameter and has four holes.

\section{CASKET HARDWARE}

\section{Brass Tacks}

Fifteen large-headed brass tacks were recovered from within the coffin matrix. The domed head of each tack has a diameter of one inch and is unadorned except for a raised or rolled decorative rim. Because of the deterioration of the coffin wood, it could not be determined if these tacks were used to hold a coffin liner in place or to decorate the outside of the coffin lid itself.

\section{Iron Tacks}

Thirty-five $3 / 8$-inch, flat-headed iron tacks were recovered during excavation. These tacks, similar to carpet tacks, were probably used to hold the inner coffin lining in place.

Nails

Four sizes of square nails were among the coffin hardware. One $10 \mathrm{~d}$ nail was found at the extreme toe end of the coffin; although no wood or nails remained in the head area, a large rust stain was found in that portion of the soil. Other nail sizes included 8d, 7d, and 3d. Several nails exhibit an interesting corrosion pattern: directly below the head of these nails is a one-inch strip of horizontally layered corrosion followed by vertically layered deposits. This corresponds to the one-inch thickness of the wood planks used in construction of at least part of the coffin. 


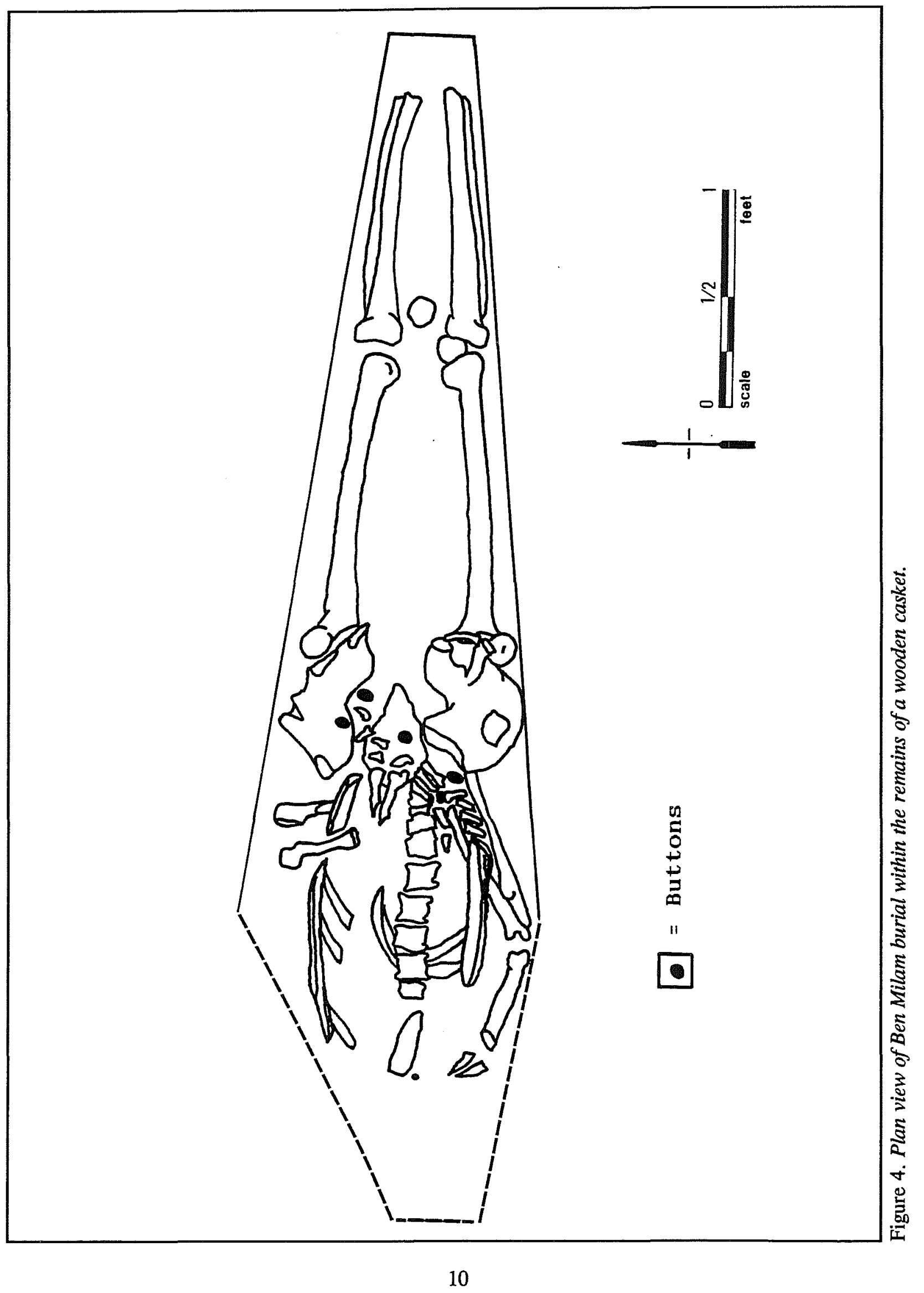




\section{CONCLUSIONS}

The details of two independent analyses of the burial recovered during this investigation are given by Winkler, Appendix A, and by Sandness and Owsley, Appendix B, at the conclusion of this report. These analyses agree that the remains are those of a right-handed Caucasian male, $5 \mathrm{ft} 7$ inches to $5 \mathrm{ft} 9$ inches tall, who was between 40 and 49 years of age at time of death. The appearance of a circular defect in the back of the skull is interpreted as the exit wound of a projectile that entered the head somewhere in the facial area. This wound, which shows no signs of healing, was the cause of death.

The skeletal pathologies identified during analysis illustrate the daily hardships, strenuous labor, and lack of dental care experienced by an individual during the founding days of the Republic of Texas. The thickened bone at points of muscle attachments and depressions in the vertebrae are also relics of the strenuous lifestyle led by individuals of the times. Indications of childhood illness are represented by the presence of dental hypoplasia, and evidence of the consumption of poorly processed foods is illustrated by the wear visible on the teeth. Evidence of degenerative joint disease, osteoarthritis, is present on several of vertebrae and pronounced at both knee joints.

These findings correspond with the known facts concerning Col. Ben Milam. He was a Caucasian male who died at the age of 47 during the Battle of San Antonio de Bejar in 1835. Eyewitness accounts record that Milam died from a single gun shot wound to the head. After the initial burial in the courtyard of the Veramendi house, Col. Milam's remains were reinterred in the center of the city cemetery. His grave was subsequently marked with a marble monument and the city cemetery was renamed Milam Park in his honor. Although the marble monument was moved during park renovations in 1976, the concrete foundation for the monument was located during our work in Milam Park. The burial was revealed beneath this foundation.
The physical interpretations combined with the archival and artifactual evidence gathered, as well as the location of the burial, firmly indicate that the remains exhumed from the center of Milam Park are those of Texas Independence hero $\mathrm{Col}$. Benjamin R. Milam.

\section{AFTERWORD}

Following Catholic and Masonic graveside services, the remains of Col. Benjamin Rush Milam were reinterred on Sunday, December 11, 1994, at the base of the monument bearing his statue in Milam Park. 


\section{REFERENCES CITED}

Collins, M. B.

1992 Quaternary Geomorphology of the San Antonio Dome Project. Manuscript on file. Center for Archaeological Research, The University of Texas at San Antonio.

Day, J. M.

1964 Benjamin R. Milam. In Heroes of Texas, pp. 115-124. Texian Press, Waco.

Fox, A. A.

1984 A Study of Five Historic Cemeteries at Choke Canyon Reservoir, Live Oak and McMullen Counties, Texas, Choke Canyon Series, No. 9. Center for Archaeological Research, The University of Texas at San Antonio.

Maxwell, D. B. S.

1993 Beer Cans: A Guide for the Archaeologist. Historical Archaeology 27:95-113.

Nevin, D.

1975 The Old West: The Texans. Time/Life Books, Alexandria, Virginia.

San Antonio Express (SAE) [San Antonio, Texas]

1878 [Untitled Supplement] 18 July.

1899 Discusses the School Board: Aldermen Vote Unanimously for an Appropriation to Place a Tablet Over the Grave of Ben Milam, Texas Hero. 19 September.

1899 Monument for Old Ben Milam: Daughters of the Republic Propose to Erect One. 7 December.

1900 [Untitled Article] 4 April:10.

1903 The Day the Alamo Fell: Sixty-Seventh Anniversary of the Event Observed. 7 March.

1938 Milam Monument is Unveiled Here. 8 September.

1946 Alamo Heroes and War Vets Honored in Ceremonies Here. 7 March.

San Antonio Light (SAL) [San Antonio, Texas]

1933 Heroes of Texas Remembered. 7 March.

Taylor, C.

1935 Tall Men With Long Rifles: The Glamorous Story of the Texas Revolution. Naylor, San Antonio.

Taylor, F. B., R. B. Hailey, and D. L. Richmond

1966 Soil Survey of Bexar County, Texas. Series 1962 (12), United States Department of Agriculture, Soil Conservation Service, Washington, D. C. 


\title{
APPENDIX A ANALYSIS OF THE BEN MILAM SKELETON
}

\author{
Barbara A. Winkler \\ Division of Behavioral and Cultural Sciences \\ The University of Texas at San Antonio \\ San Antonio, Texas 78249
}

\section{INTRODUCTION}

The bones of Texas Revolutionary hero Ben Milam were exhumed from their 1846 reburial site in what is now Milam Park, in downtown San Antonio across from Santa Rosa Hospital. By the time of the exhumation in early 1993, the wooden coffin had almost completely disintegrated, although metal coffin nails were found. Shell and bone buttons from Col. Milam's shirt and pants were also located; however, no signs of the brass belt buckle or the Masonic ring with which, according to legend, he had been reinterred (Taylor 1935:65) were found.

As excavation continued, the partially exposed lower spinal column appeared to be intact; however, the remaining bones of the upper body were either missing or fragmented, since the coffin had unwittingly been reburied in a groundwater seepage point. This inadvertency led to apparent pooling of water in the chest cavity and nearly complete destruction of the bones by groundwater action and perhaps soil pressure. As the exhumation proceeded, it became clear that, other than the femur and the tibia of the right leg, very few of the remaining bones were intact.

The skeleton was carefully removed in all its pieces, bits, and fragments and taken to the CAR laboratory for study. As the bones were cleaned, classified, and studied, some fragments of the cranium, the major long bones of the left leg, the innominates, and part of the sacrum were carefully reassembled. Some of the vertebral column was reassembled, but many of the thoracic and most of the cervical vertebrae were either missing or were too badly eroded and fragmented for reassembly.
The following section lists the bones, teeth, and skeletal fragments which were found, together with a short description of pertinent findings.

\section{CRANIUM, FACIAL BONES, AND DENTITION}

\section{CRANIUM}

Of the cranium, only fragments and pieces remain. Many parts, including most of the facial bones, are missing, probably disintegrated through groundwater action. All fragments show the two tables which make up cranial bones, indicating that no pieces of scapula were accidentally mixed in with them. Cranial fragments show no pitting.

Painstaking reassembly of the larger cranial fragments provided a partially restored cranium: parts of the right and left parietals; a part of the frontal bone containing the top of the right orbit, which could be rejoined to the right parietal near the sagittal suture line; and a large part of the occiput. Reassembled, enough of the cranium is extant to show some of the sagittal suture very clearly, part of the coronal suture, and much of the occipital suture. The sutures appear well closed, indicating that the individual was in midlife at the time of death. The blunt edge of the portion of the top right orbit of the frontal bone indicates that the individual was male.

Enough of the cranium has been reassembled to show part of a bullet hole in the skull which Dr. Vincent DiMaio, medical examiner for Bexar County, Texas, diagnosed as an exit wound. This is based on the beveling on the external surface of 
the bone, while the edges inside the head, on the cerebral surface, remain sharply delineated (Vincent DiMaio, M.D., personal communication 1993). There is no possibility that this feature is other than what it appears to be.

The wound is located close to the top of the cranium, in the left parietal, just touching the right parietal and obliterating that portion of the sagittal suture. It lies approximately seven centimeters from lambda, the craniometric point where the sagittal suture joins the occipital suture. The edges are widely beveled at perhaps a $30^{\circ}$ angle. The diameter of the bullet hole cannot be measured because the portions of the missing left parietal bone which would complete the circle were not found. The size of the part that has been reconstructed appears consistent with the diameter of a bullet from a Baker rifle, which the sharpshooters of Gen. Santa Anna's army were said to be using (Taylor 1935:65).

Considering the location of the exit wound and the angle of its passage through the skull in relation to the rest of the face (were it there), it can be tentatively speculated that the fatal shot came from below instead of from face level or above (David Henkes, M.D., personal communication 1993). The bullet would have had to hit Col. Milam somewhere in the face. He would have to have had his head raised or be looking upward, in order for the bullet to leave the skull at the point where the exit wound is located (David Henkes, M.D., personal communication 1993).

\section{Right Temporal}

The right temporal is the only intact bone of the skull that was found. The mastoid process, external auditory meatus, and internal petrous portion are all intact. The beveled edges of the squamosal suture are clearly evident; however, so much of the remaining cranium is missing that the right temporal cannot be joined to the reconstructed portion of the skull.

A small piece of the right posterior malar has been rejoined to the zygomatic process of the right temporal by the excavator. The malar is delicate, indicating small cheekbones consistent with smaller facial features.

\section{Left Temporal}

One piece of the petrous portion of the left temporal was found, along with a fragment containing the left auditory meatus, but so much of the remainder of the bone is missing that the fragments cannot be joined to the reconstructed cranium.

Parietals (Right and Left), Occiput, and Remaining Cranial Bones

The fragments are as described above. The cerebral surfaces clearly show the grooves left by the veins. The entire floor of the occiput is missing; the other bones making up the brainpan were not found.

\section{FACIAL BONES AND DENTITION}

Maxilla

The left maxilla is a fragment containing a canine and first premolar. The canine is well worn. The first premolar is also well worn, but still shows two cusps. There is some evidence of caries, also possible periodontal disease. The canine and first premolar appear very slightly rotated.

Several loose premolars were located. No detailed examination was made except to note that each was well worn. No incisors were found.

\section{Mandibles}

A left mandible fragment missing the ascending ramus, condyle, and the coronoid process is present. The mylohyoid groove and mandibular foramen are well marked. Three molars, one molar, and one second premolar are intact, but nothing more of the mandible is present.

The mandible seems small for a male, again an indication of a small face when considered with the size of the right posterior malar fragment. Smaller 
faces are sometimes considered to be a northwestern European-primarily Celtic-trait (Macieji Henneberg, M.D., personal communication 1984); some accounts indicate that Col. Milam was of Welsh extraction (Day 1964). The left third molar is at a very slightly elevated angle in the rear jaw and exhibits caries on the distal side. There is evidence of bone resorbed and roots of molars are showing. The roots are splayed (sometimes considered to be a Caucasian trait [Krogman and Iscan 1986]) and the molars generally show variations of a four-cusp pattern. The presence of the third molar indicates an individual over age 30; tooth wear corroborates the individual was in midlife.

The right mandible portion contains the third and second molars, with the third molar showing three cusps and what looks like a very small fourth cusp. It could be called "peg shaped," with a +3 cusp pattern. The right second molar is badly worn down, but shows a Y-4 cusp pattern. The right second molar also shows evidence of caries on the buccal side. The teeth are well enameled, but each tooth is badly worn.

\section{Nasal Bones}

A tiny portion of what has been tentatively described as the left nasal bone was found. No other facial bones or the hyoid bone were found or recognized.

\section{POSTCRANIAL REMAINS}

\section{VERTEBRAE}

\section{Cervical Vertebrae}

Enough pieces and fragments to identify as probably having been cervical vertebrae were recovered. All were badly eroded, with all spinous and most transverse processes broken off, fragmented, or eroded. However, one piece does show a transverse foramen.

\section{Thoracic Vertebrae}

Four vertebrae, all badly eroded and fragmented, were recovered. All processes are broken off and missing. The bone is very porous and lightweight.

\section{Lumbar Vertebrae}

All five lumbar vertebrae were present, but all were well eroded and none was intact. Some spinous processes are present, but many transverse processes are missing. The vertebrae bodies are pitted, showing deterioration, possibly from groundwater and soil leaching. Strongly marked " $Y$ " marks are present on the distal surface of the body of the twelfth thoracic and the proximal body surface of the first lumbar with some faintly similar marks on the second lumbar.

Reassembly of the lumbar vertebrae indicates the intervertebral disks were thinner than usual (Albert Sanders, M.D., personal communication 1993). If Col. Milam suffered from lower back problems, thin disks rather than the spina bifida occulta were probably the cause.

\section{RIBS}

Numerous rib pieces were found, mostly disintegrated and eroded. None was intact, and no articular ends were found or recognized. The ribs are very lightweight; again, this was possibly the result of leaching from groundwater and soil.

\section{INNOMINATES}

Innominates were present but broken, with some fragmentation at the articular edges and along the iliac crest, but enough of an ilium body of each innominate remains to show that the greater sciatic notch is narrow and therefore belongs to the male sex. Most of the ischium portion of each innominate was eroded and fragmented. A fragment of a very eroded pubic bone was found. 


\section{Right Innominate}

The right innominate was heavily pitted around the ischial portion near the acetabulum. The acetabulum shows calcified articular cartilage. The iliac crest and ilium blade were pitted.

\section{Left Innominate}

The left innominate was fragmented and strongly pitted above the acetabulum. Evidence of erosion is present within the acetabulum; however, no marked evidence of pathology is found (Albert Sanders, M.D., and David Henkes, M.D., personal communication 1993).

\section{SACRUM}

The sacrum was fragmented and strongly curved, which is a male trait. The dorsal side, where reconstructed, shows evidence of spina bifida occulta and the remains of a coccygeal vertebra. The first sacral vertebra and sacroiliac articular pieces are either missing or so fragmented they could not be recognized. Enough of the sacrum has been reconstructed to show that it is comparatively small (by today's standards), indicating a smallersized individual. It is badly eroded, very lightweight, and darkly stained from the soil.

\section{CLAVICLE}

One fragment only was recovered and is very eroded. This fragment is possibly the acromial end of the right clavicle, but this is uncertain.

\section{SCAPULA}

A possible portion of the right coracoid was recovered. No other pieces were recognized or found.

\section{STERNUM}

The gladiolus was identified, clearly showing costal notches. It is very lightweight, eroded, and fragmented. No manubrium or xiphoid process was recognized. The bone is darkly stained from contact with soil and water.

\section{UPPER EXTREMITIES}

\section{HUMERUS}

\section{Left Humerus}

The left humerus was broken into many pieces postmortem, probably from the weight of soil and water, but the pieces were not fragmented. Some pieces have apparently disintegrated, so the bone cannot be reconstructed. Strongly marked olecranon fossa and other sites of muscle attachment are indicated in some pieces. Some pitting is seen around the head and in the lesser tubercle. The humerus is eroded, although its pieces are not quite as lightweight as the vertebrae.

\section{Right Humerus}

Only pieces and fragments of the right humerus remain. The pieces are eroded and light weight. The distal end has a deep indentation above the trochlea, this resembles a large septal aperture but is not fully perforated. Muscle attachment sites are still apparent in some pieces and show possible robust muscularity (Albert Sanders, M.D., personal communication 1993).

\section{ULNA}

\section{Right Ulna}

The right ulna is $290 \mathrm{~mm}$ long and somewhat eroded. The semilunar notch, olecranon, and coronoid process are present. Muscle attachment sites (where present) are strongly marked and rough. 


\section{Left Ulna}

The left ulna was mostly in pieces and was not reassembled.

\section{RADIUS}

\section{Right Radius}

The right radius was eroded, but mostly intact. Strong muscle attachment sites are noted.

\section{CARPALS, METACARPALS, AND PHALANGES}

Carpals, metacarpals, and phalanges were recovered and separated into right and left hand, but not examined except to note that the small bones were porous and somewhat eroded.

\section{LOWER EXTREMITIES}

\section{FEMURS}

\section{Left Femur}

The left femur was found broken postmortem about $7.5 \mathrm{~cm}$ above the distal end, and was later reconstructed. It is strongly pitted at its proximal end. A small bony accretion near the head on the diaphysis near the lesser trochanter shows the attachment site of robust muscles (Albert Sanders, M.D., and David Henkes, M.D., personal communication 1993). Erosion, seen around and beneath the fovea capitis, is probably from groundwater (Albert Sanders, M.D., and David Henkes, M.D., personal communication 1993). The greater trochanter is deeply pitted, eroded, and roughened. The lesser trochanter is also very rough. The angle of the head is still oblique enough to indicate that the individual was middle-aged. The linea aspera is pronounced but rough-surfaced; it has slight pitting at the distal end of the femur. The patellar articular surface shows bony accretion, probably in connection with degenerative joint disease (Albert Sanders, M.D., personal communication 1993).

\section{Right Femur}

The right femur is $460 \mathrm{~mm}$ long and was found intact. The distal end exhibits heavy lipping around the edges of the patellar articular surface. Two calcified spurs are present on the patellar articular surface itself, one on the right side and one on the left near the outside edges. Heavy pitting is noted on the distal end. At the proximal end, the greater trochanter is pitted and heavily eroded.

Both femurs appear robust and still near normal weight after 147 years in the ground, although many of the other remaining bones are eroded and very lightweight. The curvature of the bones appears normal.

\section{PATELLA}

\section{Left Patella}

The left patella was lightweight, eroded around the edges, and pitted. A cut mark (posterior) is located on the inner surface. Some lipping is found around the articular edges.

Right Patella

A small bony spur is found on the articular surface of the right patella. Some lipping occurs around the articular surface edges.

\section{TIBIAS}

\section{Left Tibia}

A single postmortem fracture is found close to the distal end. The medial malleolus is eroded and roughened. The articular surfaces show serious degenerative joint disease. The proximal epiphysis is somewhat demineralized and pitted. 
Right Tibia

The right tibia is intact ( $390 \mathrm{~mm}$ long), with a pitted medial malleolus. The distal end has a darker stain which runs up the lower end of the diaphysis; we can speculate that the stains are from the leather boots in which Milam is reputed to have been buried. Heavy lipping is present around the condylar articular edges. The spurs on the patellar surface of the right femur probably rubbed against the proximal tibia at this point (Albert Sanders, M.D., personal communication 1993). Both tibias appear slightly bowed.

\section{FIBULA}

The left and right fibula are represented by fragments, pieces, and a pitted styloid process.

\section{TARSALS, METATARSAL, PHALANGES}

Tarsals, metatarsals, and phalanges were grouped according to right and left foot. The calcanei of both feet are extremely lightweight and eroded, as are all other tarsal bones and bones of the feet. Other than the calcanei, bones were not individually examined.

\section{DISCUSSION}

I am quite confident that the skeletal remains are those of Col. Milam for the following reasons. The bones were recovered in the proper historical site and the skull bears an exit wound from a fairly large bullet. All recovered skeletal and dental markers point to a middle-aged, Caucasian male about 67 inches tall. Measurements of the entire right leg for estimation of stature were made in situ with a steel tape measure, and again in the laboratory, using a metric yardstick in the absence of an osteometric board. The tape and yardstick measurements are in agreement. The right femur and tibia were measured separately in the laboratory, as was the right ulna. Computation of the estimate of stature was performed using the length of the femur and the equation and regression factor set out in Bass (1987:222) According to our estimates, Col. Milam was probably of average height for his time. Although he was undoubtedly heroic, his long bones indicate he was not the sixfoot-tall hero depicted in legend and by various patriotic statues.

Although they have been in the ground for 147 years, the skeletal remains still indicate Col. Milam was a robust, probably well-muscled individual who was well into middle-age at the time of his death. However, evidence of congenital lower back trouble in his spine and degenerative joint disease in the joints of the lower extremities is seen. The right knee appears especially badly arthritic. The degree of degenerative joint damage present in the knees gives a certain amount of credence to one report that Col. Milam used a cane-the cane with which Milam reportedly drew a line in the dust and asked for volunteers to step over and fight for Texas independence (Nevin 1975). No record of Col. Milam's handedness has been located; however, the heavy muscle attachment sites still apparent on the remains of his right arm might be consistent with the use of a cane, and the damaged knees might have made the use of a cane very helpful to him. Sitting astride a horse, running, or even rapid walking must have been very painful for Milam (Albert Sanders, M.D., personal communication 1993).

Col. Milam's recovered teeth are all well worn and marked evidence of dental disease is present. Many teeth showed caries, although the cavities were not yet deeply eroded; the molars were especially afflicted. All recovered mandibular and maxillary bones exhibit possible periodontal disease. These findings are consistent with the time in which he lived, one of little or no dental hygiene. Col. Milam may also have had occasional trouble with a right wisdom tooth.

The study findings appear consistent with what is known of Col. Milam and his life, a life that was strenuous, with some time spent in Mexican prisons before his final return to the nascent Republic of Texas, where he met his death by head wound during the Battle of San Antonio in December 1835. 


\section{REFERENCES CITED}

Bass, W. M.

1987 Human Osteology: A Laboratory and Field Manual, 3rd ed., Special Publication No.2. Missouri Archaeological Society, Columbia.

Day, J. M.

1964 Benjamin R. Milam. In Heroes of Texas, pp. 115-124. Texian Press, Waco.

Krogman, W. M., and M. Y. Iscan

1986 The Human Skeleton in Forensic Medicine. Charles C. Thomas, Springfield.

Nevin, D.

1975 The Old West: The Texans. Time/Life Books, Alexandria, Virginia.

Taylor, C.

1935 Tall Men With Long Rifles: The Glamorous Story of the Texas Revolution. Naylor, San Antonio. 


\title{
APPENDIX B \\ ANALYSIS OF THE SKELETAL REMAINS
}

\author{
Karin L. Sandness and Douglas W. Owsley \\ Department of Anthropology \\ National Museum of Natural History \\ Smithsonian Institution, Washington, D.C. 20560
}

\section{CONDITION OF BONE AND OSTEOLOGICAL INVENTORY}

Although many of the cranial and postcranial bones are fragmented, with some reconstruction (gluing) having taken place, the bones that are present are generally solid, dense, and in fair to good condition. No stains are apparent on the bones to indicate contact with shroud pins or with a wood or metal coffin and coffin hardware.

The cranium is incomplete and fragmented and shows evidence of both perimortem trauma, as well as postmortem damage, probably resulting from ground pressure and crushing. Present are four large pieces and 25 fragments of the cranial vault, and the left half and an anterior section of the right half of the mandible. The bones include:

- the anterior right half of the frontal, with a portion of the left parietal still attached

- the right temporal, with part (about half) of the zygomatic process

- the left temporal

- the partial left and right parietals

- the partial occipital (squamous and area around the foramen magnum)

- left and right nasal bones

- a part of the left maxilla

Postcranial bones present are the following:

- the first and second cervical vertebrae, and two centra, one with a small piece of the neural arch attached, in the range of cervicals 3-6

- thoracic vertebrae $10-12$, the neural arches of two thoracics and the small fragments of five other thoracics between 1 and 9
- lumbar vertebrae 1-5

- the partial sacrum (which probably had a sixth segment now missing)

- the complete right innominate and nearly complete (missing the pubic symphysis) left innominate

- the body of the sternum (gladiolus)

- rib fragments

- partial right and left clavicles

- the right scapula, represented by the acromium and the coracoid process

- the partial right and left humeri, both lacking the proximal third of the diaphysis

- the complete right and partial left ulnae (missing the distal third and part of the middle third)

- the complete right and partial left radii (midshaft missing, but proximal and distal ends present)

- hand bones

- the right and left femora

- the right and left patellae

- the right and left tibiae and fibulae

- foot bones, including the right and left calcanei and tali

- other small, unidentifiable fragments

The following teeth are present:

- the maxillary left first and second molars

- the mandibular left second molar and first, second, and third molars

- the right canine and first and second premolars

- the socket of the maxillary third molar is present, the tooth having been lost postmortem, as were the first and second mandibular incisors 


\section{PHYSICAL CHARACTERISTICS}

All features of the innominates are consistent with designation as male, including a relatively narrow sciatic notch and the lack of a sharp distinction between the postauricular and auricular surfaces. The curvature of the sacrum is consistent with male as are the overall size and robusticity of the long bones. Cranial morphology suggesting that sex is male includes the slope of the frontal, slight brow ridge development, moderate size of the mastoid process, small but well-defined supramastoid crest, moderate development of the nuchal ridge (i.e., the left half-the right half is missing), and the clearly defined area of attachment of the temporalis muscle.

The overall outline of the skull, the angle and morphology of the fragmentary nasal bones, the curvature of the femora, and tooth cusp morphology suggest that race is Caucasian.

The cranial sutures show the following stages of closure: the coronal is open endocranially but shows beginning ectocranial closure; the anterior third of the sagittal suture is fully united endocranially and the suture is nearly obliterated ectocranially; the lambdoidal suture is obliterated endocranially but still visible ectocranially, though closure is nearly complete. The meningeal grooves of the cranial vault are deeply and clearly defined. Dental wear on the molars that are present is moderate, with blunting of cusps and initial dentin exposure, and beginning alveolar bone resorption is occurring. The skeleton shows widespread degenerative disease-that is, slight to moderate osteophyte development and porosity on vertebrae, on the temporomandibular joint and mandibular condyle, and on the joint margins and surfaces of long bones and patellae. In addition to osteoarthritis, the lower spine shows disc herniation as a result of biomechanical stress. The right acetabulum shows periarticular lipping on the margin, and the right auricular surface, though compact with a dense surface, shows slight microporosity on the inferior one third. These various skeletal traits are consistent with an age range at death of 40 to 49 years.
Both humeri show development (enthesophytes or bony ridges) at the attachment sites of the brachioradialis and extensor carpi radialis longus muscles, but such development is substantially greater on the right than the left, indicating that this man was right-handed, as well as that he had engaged in some long-term activity placing biomechanical stress on the arms.

Based on length of the femora, stature was five feet nine inches (Trotter 1970:71-83). The size of the long bones and the development of muscle attachment sites suggest that this man was robust but not especially large; that is to say, he was moderately tall and stocky.

\section{PATHOLOGY}

\section{DENTAL}

Deposits of calculus on the two maxillary and seven mandibular teeth are slight, and wear ranges from slight (on the more anterior teeth) to moderate. No evidence of antemortem or perimortem abscessing is present. The left mandibular second and third molars show the onset of carious lesions on their occlusal surfaces. Present on the mandibular canine is a pronounced hypoplastic line, and one hypoplastic line is also present on the first premolar. Enamel hypoplasia indicates an episode of malnutrition or disease with high fever during early childhood when enamel apposition is occurring.

\section{CONGENITAL}

The sacrum displays a fairly large sacral hiatus; that is, the neural tube of at least two segments is open, representing a failure to fuse because of a minor neural tube defect. The condition is often confused with spina bifida occulta (see Barnes 1994:50). 


\section{ANTEMORTEM TRAUMA}

The right superior articular facet of the neural arch of one of the thoracic vertebrae in the range of the first through the ninth shows a healed fracture line, indicating an old (antemortem) injury to the back.

\section{PERIMORTEM TRAUMA}

A circular defect is present in the left parietal that overlaps the sagittal suture and extends into the right parietal. The anterior, right lateral, and part of the inferior posterior borders of the defect are present; the left inferior margin would have been in an area of bone that is missing. On initial inspection, the fracture edge has the appearance of remodeling, but close examination suggests that postmortem crystallization (i.e., calcium carbonate formation) occurred along the fracture; the beveled ectocranial margin of the defect shows no healing, and the margin is weathered. The diameter of the defect is approximately $19.5 \mathrm{~mm}$; when the beveled area surrounding the defect is included, the diameter is $30.0 \mathrm{~mm}$. Although radiographs of the area of the defect show no traces of metal, its appearance suggests that it is the exit wound of a projectile that entered the left side of the frontal or the face (areas of missing bone, thus the exact point of entry cannot be established).

A small depression is present along the anterior margin of the fracture. The presence of both beveling and this depression is difficult to interpret, for the depression is inconsistent with a typical gunshot wound. It is probably the result of some postmortem process, or possibly the gunshot exited from an area that had sustained some antemortem injury.

Four radiating fractures extend from the defect: the most anterior traverses the right parietal, and a second fracture runs parallel and about $20 \mathrm{~mm}$ posterior to it; a third fracture parallels the sagittal suture and travels toward the occipital; and the fourth traverses the left parietal and continues laterally in the direction of the first fracture. As there is missing bone on the left anterior side of the defect, it is not possible to identify other radiating fractures that were probably present.

\section{INFECTIOUS DISEASE}

There is no osteological evidence of periostitis or osteomyelitis.

\section{DEGENERATIVE DISEASE}

Both the right temporomandibular joint and the right mandibular condyle show slight porosity and erosion.

The first cervical vertebra shows very slight osteophytic lipping and porosity on the articular facets, and one of the partial cervicals between 3 and 6 shows slight osteophyte development on the centrum and slight porosity. The margins of the articular facets of one of the neural arches representing a thoracic vertebra between 1 and 9 also show slight osteophytic lipping, and the eleventh thoracic shows slight porosity but no osteophytes. The twelfth thoracic vertebra is slightly compressed, that is, the centrum shows a small decrease in height and wedging on the anterior margin. The margins of the five lumbar vertebrae are normal, although the first-like the twelfth thoracic-shows a slight loss in the normal thickness of the centrum and wedging on the anterior margin.

The proximal end of the right femur shows no arthritic changes, but on the distal end are pronounced osteophytes on both the margin and the joint surface and slight porosity. The left femur also shows pronounced osteophyte development at the distal end. There is marginal lipping, and the joint surface has thickened nodules of bone and also shows slight porosity. Osteophytes are present on the articular surface margins of both patellae, and the joint surfaces show slight porosity. The left patella is more remodeled than the right and its contour is more irregular. The proximal end of the left tibia shows severe osteophyte formation, with a distinct rim around both margins and involvement 
of the joint surface, which also shows slight porosity. The distal end is normal, as is that of the right tibia. The proximal end of the right shows moderate osteophytic lipping on the margins, with slight porosity on the joint surface. Neither fibula shows any pathology.

The distal joint surfaces of the right and left humeri are normal (the proximal thirds are missing), as are the proximal and distal joint surfaces of the right ulna. The distal end of the left ulna is missing, but the proximal joint surface is normal, and both radii are normal.

In addition to osteoarthritis, this individual suffered from the effects of biomechanical stress to the lower spinal column as evidenced by Schmorl's disease. Only half the centrum of the tenth thoracic vertebra is present, but the partial superior and inferior end plates each have one small Schmorl's depression. The inferior end plate of the eleventh thoracic vertebra has three large Schmorl's depressions. The twelfth thoracic, in addition to the previously mentioned wedging and loss of height, has two small Schmorl's depressions on both the superior and inferior end plates. Two distinct Schmorl's depressions are also present on the superior end plate of the first lumbar vertebra (which like T-12 displays wedging of the anterior margin and a slight loss of height). The superior end plate of the second lumbar has a V-shaped Schmorl's depression, and the inferior end plate shows a similar but smaller depression. The superior end plate of the third lumbar has a small Schmorl's depression, and the inferior end plate, an extremely small one. The fourth lumbar displays a crescent-shaped depression $25 \mathrm{~mm}$ long and about $7.5 \mathrm{~mm}$ wide (at the widest point), with cancellous bone visible. The inferior end plate of this vertebra has two depressions each measuring about $2.3 \mathrm{~mm}$ in diameter. The fifth lumbar is normal.
The disc herniation present in the three lower thoracics and the first four lumbar vertebrae indicate an injury or the effects of heavy labor exerting biomechanical stress on the back. The enthesophytes (bony development) at muscle attachment sites on the upper arms and legs and on the ischia are further evidence of such activity and strain.

\section{CONCLUSIONS}

The skeleton described in the preceding sections represents a robust, active, right-handed, white male who was about 5 feet 9 inches tall. He was 40-49 years of age at death. At the time of death, which resulted from perimortem trauma (a gunshot wound) to the head, he was suffering from osteoarthritis, which was most pronounced at the knee joints, and from extensive disc herniation in the lower spine. The latter condition, together with well-developed muscle attachment sites, indicates heavy labor or some other activity involving substantial biomechanical stress. 


\section{REFERENCES CITED}

Barnes, E.

1994 Developmental Defects of the Axial Skeleton in Paleopathology, University Press of Colorado, Niwot.

Trotter, M.

1970 Estimation of Stature from Intact Limb Bones, In Personal Identification in Mass Disasters, edited by T. D. Stewart, pp. 71-83. Smithsonian Institution, Washington, D. C. 
. 


